\title{
Treatment of carpal and digital ganglions by simple aspiration, or aspiration and injection of corticosteroid and/or hyaluronidase
}

\author{
John T Seki MD, Michael SG Bell MD FRCSC FACS \\ Ottawa Civic Hospital, University of Ottawa, Ottawa, Ontario
}

JT Seki, MSG Bell. Treatment of carpal and digital ganglions by simple aspiration, or aspiration and injection of corticosteroid and/or hyaluronidase. Can J Plast Surg 1997;5(4):233-237. This retrospective study examined the treatment outcome of 178 carpal and digital ganglion cysts by simple aspiration or aspiration and injection of corticosteroid (triamcinolone acetonide $40 \mathrm{mg} / \mathrm{mL}$ ) and/or hyaluronidase in 174 patients between 1987 and 1995. A total of 106 ganglions were treated with aspiration and triamcinolone acetonide injection; the cumulative cure rates were $45.3 \%, 50.0 \%$ and $53.8 \%$ following one, two or three treatments, respectively. The cure rates were similar in 23 ganglions in the hyaluronidase group: $43.5 \%, 52.2 \%$ and $56.5 \%$, respectively. Seventeen of the 23 ganglions treated with a combination of triamcinolone acetonide and hyaluronidase recurred, yielding success rates of $17.4 \%$ and $26.1 \%$ following two or three treatments, respectively. Twenty-six ganglions were treated with simple aspiration. Of these, 23 were volar digital ganglions. The success rates were $61.5 \%$ and $69.2 \%$ following one or two treatments, respectively. The overall success rate was 94 of $178(52.8 \%)$ after a maximum of three treatments, regardless of the type of treatment and the anatomical location of the ganglions. This study provided baseline data following nonoperative management of ganglions; the data can be compared with those from a planned prospective randomized clinical trial involving the use of rolitetracycline as a sclerosing agent, which is currently under review by the Ethics Committee at the authors' institution.

Key Words: Chart review, Corticosteroid, Ganglion cysts, Hyaluronidase, Simple aspiration

Traitement des ganglions carpiens et digitaux par simple aspiration ou aspiration et injection de corticostéroïdes et/ou d'hyaluronidase

RÉSUMÉ : Cette étude rétrospective se penchait sur les résultats du traitement de 178 kystes des ganglions carpiens et digitaux par simple aspiration ou aspiration et injection de corticostérö̈des (acétonide de triamcinolone à $40 \mathrm{mg} / \mathrm{mL}$ ) et/ou d'hyaluronidase chez 174 patients entre 1987 et 1995. En tout, 106 ganglions ont été traités par aspiration et injection d'acétonide de triamcinolone; les taux de guérison cumulatifs ont été de 45,3\%,50,0\% et 53,8\% après un, deux ou trois traitements, respectivement. Les taux de guérison ont été semblables pour 23 ganglions traités à l'hyaluronidase : 43,5\%,52,2\% et 56,5\%, respectivement. Dix-sept des 23 ganglions traités par acétonide de triamcinolone combiné à l'hyaluronidase sont revenus, donnant des taux de succès de $17,4 \%$ et $26,1 \%$ après deux ou trois traitements, respectivement. Vingt-six ganglions ont été traités par simple aspiration; parmi ceux-ci, 23 étaient des ganglions digitaux palmaires. Les taux de succès ont été de $61,5 \%$ et $69,2 \%$ après un ou deux traitements, respectivement. Le taux de succès global a été de 94/178 (52,8 \%) après un maximum de trois traitements, peu importe le type de traitement et la localisation des ganglions. Cette étude a fourni les données de base après un traitement non chirurgical des ganglions. Les données peuvent être comparées à celles d'essais cliniques randomisés prospectifs prévus mettant en jeu le recours à de la rolitétracycline comme agent sclérosant, intervention actuellement étudiée par le comité de déontologie de l'établissement des auteurs.

$\mathrm{G}$ anglion cysts comprise $50 \%$ to $70 \%$ of all soft tissue tumours of the hand (1). They are most commonly found on the dorsal aspect of the wrist, followed by the anterior wrist (2-7). Their respective origins are the scapholunate

Correspondence and reprints: Dr Michael SG Bell, 1919 Riverside Drive, Suite 402, Ottawa, Ontario K1H 1A2. Telephone 613-739-5424, fax 613-739-7168 ligament and the scaphotrapezoid ligament/radiocarpal joint capsule (5,8-10). Their etiology remains elusive. However, postulated pathogenesis of ganglions include retention cysts, herniation of tendon or capsular synovium, bursal transformation, neoplasm and mucinous degeneration of connective tissue $(2,6,8,11,12)$. Most patients present with mild local tenderness, discomfort or mild weakness that limits, in some way, their activities of daily living.

Various conservative methods have been previously ad- 


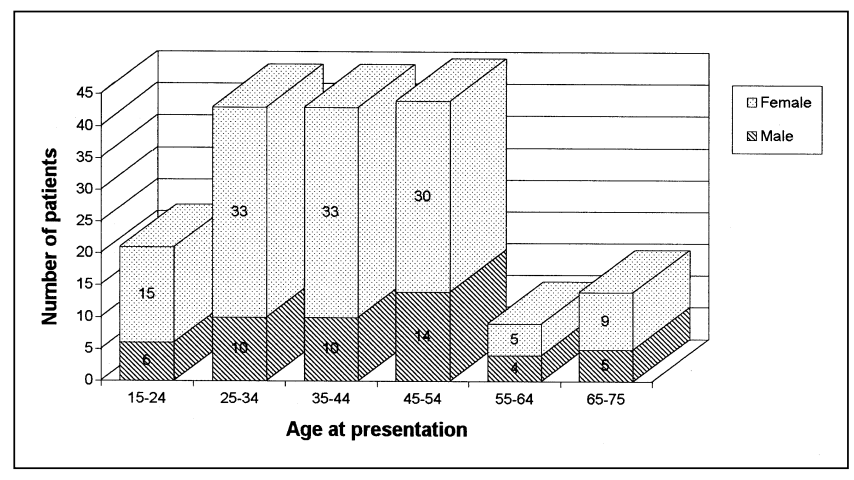

Figure 1) Frequency distribution of patient age at presentation

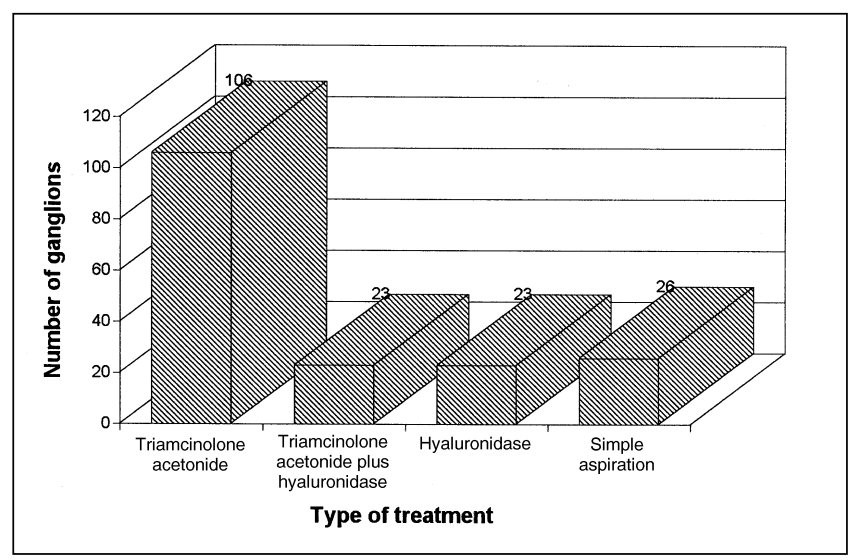

Figure 2) Frequency distribution of the types of treatment

vocated for the treatment of carpal and digital ganglions. These include manual rupture, needle aspiration with or without injection of corticosteroids and sclerosing agents, all with varying success rates $(1-4,6,7,9,13,14,16)$, which indicates that there is no established definitive treatment. The purpose of this study is to evaluate the treatment outcome following simple aspiration or aspiration and injection of corticosteroid and/or hyaluronidase.

\section{PATIENTS AND METHODS}

Between 1987 and 1995, 350 patients were selected for chart review. (Excluded were patients with mucous cysts of the distal interphalangeal joint and those who had previous surgical or nonsurgical treatment for carpal and digital ganglions.) These 350 patients were seen in the private office or the plastic surgery clinic by one surgeon at our hospital. The skin overlying each ganglion was prepped and locally infiltrated with $1 \%$ or $2 \%$ xylocaine with adrenaline, using a 25 gauge needle followed by simple aspiration with an 18 gauge needle, or aspiration and injection with corticosteroid (triamcinolone acetonide $40 \mathrm{mg} / \mathrm{mL}$ ) or hyaluronidase. The ganglions were localized to the dorsal wrist, volar wrist and volar aspect of digits. There was no restriction in activity posttreatment. Patients treated on subsequent visits with triamcinolone acetonide and hyaluronidase were classified under a separate treatment group. In the majority of digital ganglions, only aspiration was performed because localiza-

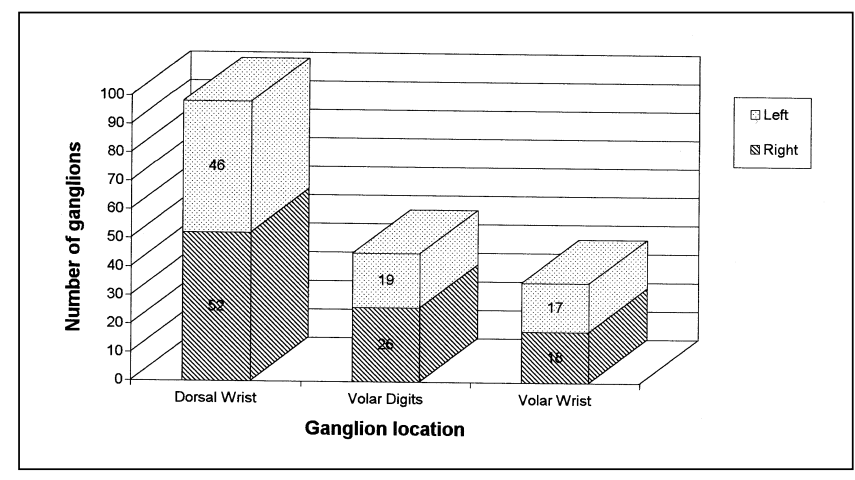

Figure 3) Frequency distribution of ganglion location

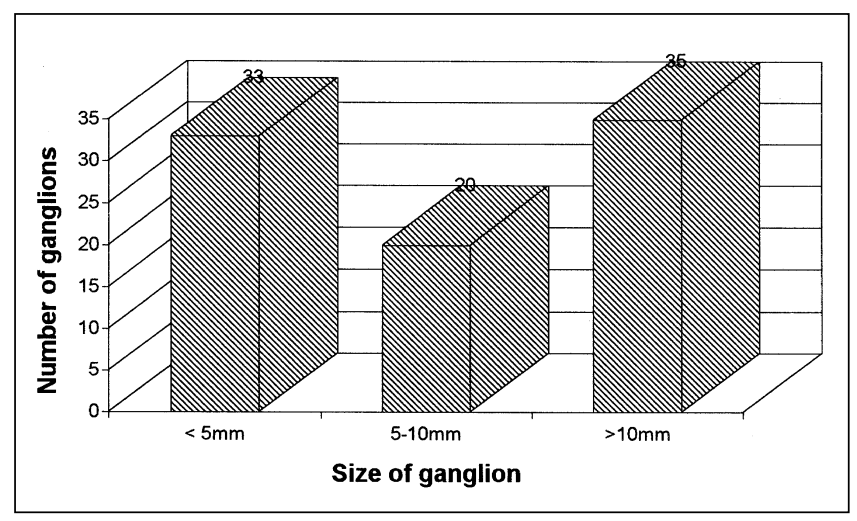

Figure 4) Frequency distribution of ganglion size

tion was too difficult to facilitate injection of one of the two agents.

Of the 350 patients, 174 with 178 carpal and digital ganglions were contacted by telephone after multiple attempts over an eight-week period. Specific questions asked during the telephone interview included whether there was recurrence of the ganglion; how soon after the first treatment recurrence was noticed; and if specific adverse reactions were encountered, ie, redness, swelling or skin colour changes at the site of the injection. Patient responses were recorded only if they were certain upon questioning. This information, along with patient files, provided the database with which cure rates were calculated.

\section{RESULTS}

In this series of 174 patients with 178 ganglions, follow-up to the time of the telephone interview averaged 35.1 months (range four to 109 months). There were 49 males and 125 females; average age was 40.1 years (range 14 to 75 years, Figure 1). There were four treatment categories: triamcinolone acetonide; triamcinolone acetonide plus hyaluronidase; hyaluronidase; and simple aspiration (Figure 2). Anatomical location of the ganglions include dorsal wrist (98 of 178, $55.1 \%$ ), volar wrist $(33$ of $178,18.5 \%$ ) and volar aspect of digits (47 of 178, 26.0\%) with 96 right-sided and 82 leftsided (Figure 3). Bilateral ganglions were present in three patients. Carpal tunnel syndrome, ipsilateral to the side of the 
TABLE 1

Treatment results

\begin{tabular}{|c|c|c|c|c|c|}
\hline $\begin{array}{l}\text { TREATMENT/ } \\
\text { location }\end{array}$ & \multicolumn{3}{|c|}{ Cure rates specific to treatment } & $\begin{array}{c}\text { Recurrence after } \\
1,2 \text { or } 3 \text { treatments }\end{array}$ & $\begin{array}{l}\text { Cure rates specific to } \\
\text { anatomical site }\end{array}$ \\
\hline \multicolumn{6}{|c|}{ TRIAMCINOLONE ACETONIDE } \\
\hline Volar wrist & 6 & 1 & 0 & 16 & $7 / 23(30.4 \%)$ \\
\hline Volar digits & 12 & 1 & 1 & 3 & $14 / 17(82.4 \%)$ \\
\hline
\end{tabular}

\section{HYALURONIDASE}

$\begin{array}{lcc}\text { Dorsal wrist } & 5 & 1 \\ \text { Volar wrist } & 2 & 1 \\ \text { Volar digits } & 3 & 0 \\ \text { Total \# of patients } & \text { Total: } 10 & \text { Cumulative total: } 12 \\ \text { treated: } 23 & \text { Cure rate: } 45.3 \% & \text { Cure rate: } 52.5 \%\end{array}$

1
0
0

Cumulative total: 13 Cure rate: $56.5 \%$

\section{TRIAMCINOLONE ACETONIDE AND HYALURONIDASE}

Dorsal wrist
Volar wrist
Volar digits
Total \# of patients
treated: 23

0
0
0
Total: 0
Cure rate: $0 \%$

\section{SIMPLE ASPIRATION}

\begin{tabular}{lcc} 
Dorsal wrist & 0 & 0 \\
Volar wrist & 0 & 0 \\
Volar digits & 16 & 2 \\
Total \# of patients & Total: 16 & Cumulative total: 18 \\
treated: 26 & Cure rate: $61.5 \%$ & Cure rate: $69.2 \%$ \\
\hline
\end{tabular}

$\begin{array}{cc}3 & 1 \\ 1 & 0 \\ 0 & 1 \\ \text { Cumulative total: } 4 & \text { Cumulative total: } 6 \\ \text { Cure rate: } 17.4 \% & \text { Cure rate: } 26.1 \%\end{array}$

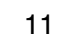

4

2

Total: 17

$$
\begin{gathered}
7 / 14(50.0 \%) \\
3 / 5(60.0 \%) \\
3 / 4(75 \%)
\end{gathered}
$$

Total: 10 
previously advocated, including surgical excision, subcutaneous discission with tenotome and a wide range of conservative therapies, such as manual rupture, transfixation with a suture, and needle aspiration with or without injection of corticosteroid, hyaluronidase, proteolytic enzyme or sclerosing agents $(2,6,13,14,17-20)$. With the exception of surgery and needle aspiration with or without corticosteroid/ hyaluronidase injection, other methods have fallen out of favour because of a lack of effect or the risk of potential complications $(20,21)$.

From our data, it is apparent that the cumulative success rates following multiple treatments are more favourable than those after the initial treatment. Unfortunately, the sample size, with the exception of 106 ganglions in the triamcinolone acetonide group, is too small to make any meaningful statistical comparison between the different groups. However, a few general trends deserve comment.

The cumulative success rate of $53.8 \%$ for our corticosteroid (triamcinolone acetonide) group was less favourable than results from other studies (hydrocortisone: 26 of 30, $87 \%$ [16]; hydrocortisone $25 \mathrm{mg} / \mathrm{mL}: 19$ of $22,86 \%$ [13]; triamcinolone: 24 of 37, 65\% [6]; methylprednisolone $40 \mathrm{mg} / \mathrm{mL}$ : 27 of 34, 79\% [4]). Our larger sample sizes may be more representative of the true population mean. Nevertheless, by any clinical standards, a success rate of $53.8 \%$ is unsatisfactory. Our larger sample sizes may be more representative of the true population mean.

Compared with dorsal wrist and digital ganglions, volar wrist ganglions were observed to be most recalcitrant to treatment. This concurs with results from a study by Wright et al (9) in 1994 in which 20 of 24 volar wrist ganglions recurred following aspiration and corticosteroid injection. The reason that volar wrist ganglions may have higher recurrence rate may be explained in a study by Andren and Eiken (8) in 1971, in which $85 \%$ of volar wrist ganglions were found to have a communication with the wrist joint following arthrograms compared with $44 \%$ of dorsal wrist ganglions.

Volar digital ganglions appeared to have the highest cure rates in any treatment group, which is consistent with previous studies $(17,22)$. To our knowledge, there are no studies that demonstrate a communication between digital ganglions and the flexor tendon sheath. If we propose that there is an increased risk of recurrence in the presence of a communication between the ganglion and the joint space, its corollary must state that the absence of a communication between a flexor tendon sheath and a digital ganglion will reduce its recurrence (17).

\section{REFERENCES}

1. Angelides AC. Ganglions of the hand and wrist. In: Green DP, ed. Operative Hand Surgery, 2nd edn, vol 3. New York: Churchill Livingstone, 1988:2283-98.

2. Carp L, Stout AP. A study of ganglion, with reference to treatment. Surg Gynec Obstet 1928;47:460-8.

3. Zubowicz VN, Ishii $\mathrm{CH}$. Management of ganglion cysts of the hand by simple aspiration. J Hand Surg 1987;12A:618-20.

4. Holm PCA, Pandey SD. Treatment of ganglia of the hand and wrist with aspiration and injection of hydrocortisone. Hand 1973;5:63-7.
A limitation of this study is the small sample size, which questions the validity of any study and makes inferences regarding the general population inaccurate. Sample sizes under 30 , as in three of the four treatment groups, will generally fail to produce any statistical significance in its analysis.

Of the 350 eligible patients for the study, only 174 were reached by telephone, giving a response rate of $49.7 \%$. A flaw of telephone interviewing is the introduction of recall error, especially for events that occurred as long as eight years ago. We attempted to minimize this by asking mostly for yes/no responses and by recording the data only when patients were certain of their responses.

Overall, the results following conservative treatment were relatively poor considering that spontaneous regression rates of $38 \%$ to $58 \%$ have been observed in the absence of any treatment $(2,14,23)$.

It has been suggested that surgery offers the best success rate (4) provided that radical excision - removal of the cyst, stalk and the 'base plate' (consisting of a circular segment of a joint capsule) - is performed $(14,24,25)$. Success rates of $95 \%$ to $100 \%$ following adherence of the above guideline have been reported $(14,24)$. However, it is our opinion that ganglions are benign lesions, and as such, we must adhere to the principle of "First, do no harm". We believe that surgery is too invasive a procedure for a gain that is proportionately minimal and should never be advocated for a primary lesion. For patients who seek the surgical option, potential complications must be made understood and the possibility of harm outweighing benefit must be emphasized. Despite the effectiveness of surgery, its potential complications, prolonged recovery time, loss of productivity and high cost (estimated in 1987 at US $\$ 1200$ compared with US $\$ 100$ for an office aspiration) have already rendered this option less popular (3).

At our institution the various nonsurgical methods employed in the treatment of ganglions have yielded unsatisfactory results. However, given our bias for conservative management for this condition we are currently awaiting approval to commence a prospective randomized controlled clinical trial using rolitetracycline as a sclerosing agent following aspiration of carpal and digital ganglions. To our knowledge, tetracycline (rolitetracycline) has not been used as a sclerosing agent in the treatment of ganglion cysts. Tetracycline has been successfully administered in sclerotherapy in a variety of clinical situations $(15,21,26-30)$. In addition, rolitetracycline is inexpensive, simple to administer and has no significant recovery time, all of which fulfil the criteria for an ideal therapeutic agent.

5. Seidman GD, Margles SW. Dorsal wrist ganglion presenting as anterior wrist ganglion. J Hand Surg 1994;19A:959-60.

6. Nelson CL, Sawmiller S, Phalen GS. Ganglions of the wrist and hand. J Bone Joint Surg 1972;54A:1459-64.

7. McEvedy BV. Simple ganglia. Br J Surg 1962;49:585-94.

8. Andren L, Eiken O. Arthrographic studies of wrist ganglions. J Bone Joint Surg 1971;53A:299-302.

9. Wright TW, Cooney WP, Ilstrup DM. Anterior wrist ganglion. J Hand Surg 1994;19A:954-8. 
10. Greendyke SD, Wilson M, Shepler TR. Anterior wrist ganglion from the scaphotrapezial joint. J Hand Surg 1992;17A:487-90.

11. Zachariae L, Vibe-Hansen H. Ganglia: Recurrence rate elucidated by a follow-up of 347 operated cases. Acta Chir Scand 1973;139:625-8.

12. Soren A. Pathogenesis and treatment of ganglion. Clin Orthop 1966;48:173-9.

13. Derbyshire RC. Observations on the treatment of ganglia, with a report on hydrocortisone. Am J Surg 1966;112:635-6.

14. Hvid-Hansen O. On the treatment of ganglia. Acta Chir Scand 1970;136:471-6.

15. Treece GL, Georgitis WJ, Hofeldt FD. Resolution of recurrent thyroid cysts with tetracycline instillation. Arch Intern Med 1983;143:2285-7.

16. Becker W. Hydrocortisone therapy in ganglia. Industr Med Surg 1953;22:555-7.

17. Richman JA, Gelberman RH, Engber WD, et al. Ganglions of the wrist and digits: Results of treatment by aspiration and cyst wall puncture. J Hand Surg 1987;12A:1041-3.

18. Dao LJ. A new method of treatment of ganglions and synovial cysts. J Occup Med 1964;6:217-20.

19. Ball EJ. A new treatment of ganglion. Am J Surg 1940;50:722-3.

20. Mackie IG, Howard CB, Wilkins P. The dangers of sclerotherapy in the treatment of ganglia. J Hand Surg 1984:9B:181-4.

21. Key JA. Treatment of ganglion by injection of caroid. A Dangerous Procedure. JAMA 1942;118:516-7.

22. Korman J, Pearl R, Hentz VR. Efficacy of immobilization following aspiration of carpal and digital ganglions. J Hand Surg 1992;17A:1097-9.

23. McEvedy BV. The simple ganglion: A review of modes of treatment and an explanation of the frequent failures of surgery. Lancet 1954;i:135-6.

24. Angelides AC, Wallace PF. The dorsal ganglion of the wrist: Its pathogenesis, gross and microscopic anatomy, and surgical treatment. J Hand Surg 1976;1:228-35.

25. Bogumill GP, Sullivan DJ, Baker GI. Tumors of the hand. Clin Orthop 1975;108:214-22.

26. Goldfarb WB, Bigos ST, Nishiyama RH. Percutaneous tetracycline instillation for sclerosis of recurrent thyroid cyst. Surgery 1987;102:1096-100.

27. Rencken RK, Bornman MS, Reif S, et al. Comparative trial of sclerotherapy for hydroceles. Br J Urol 1990;65:382-4.

28. Echavez MI, Lee KC, Sooy CD. Tetracycline sclerosis for treatment of benign lymphoepithelial cyst of the parotid gland in patients infected with human immunodeficiency virus. Laryngoscope 1994;104:1499-502.

29. El-Mufti M. Sclerotherapy of the human gall bladder using ethanol and tetracycline hydrochloride. Br J Surg 1993;80:916.

30. Sitzmann JV, Dufresne C, Zuidema GD. The use of sclerotherapy for treatment of post mastectomy wound seromas. Surgery 1983;93:345-7.

31. Walker-Renard PB, Vaughn LM, Sahn SA. Chemical pleurodesis for malignant pleural effusions. Ann Intern Med 1994;120:56-64. 